\title{
Adding palm oil to the diet of sheep alters fatty acids profile on yogurt: Benefits to consumers
}

\author{
ANDERSON E. BIANCHI ${ }^{1}$, ALEKSANDRO S. DA SILVA ${ }^{2}$, ANGELISA H. BIAZUS ${ }^{2}$, NEILA S.P.S. RICHARDS ${ }^{3}$, \\ LUIS G. PELLEGRINI ${ }^{3}$, MATHEUS D. BALDISSERA ${ }^{4}$, VICENTE P. MACEDO ${ }^{5}$ and ANDRÉ L.F. DA SILVEIRA ${ }^{6}$ \\ ${ }^{1}$ Programa de Pós-Graduação em Zootecnia, Setor de Ciências Agrárias, Universidade Federal \\ do Paraná, Rua dos Funcionários, 1540, 80035-050 Curitiba, PR, Brazil \\ ${ }^{2}$ Programa de Pós-Graduação em Zootecnia, Centro de Educação Superior do Oeste, Universidade do \\ Estado de Santa Catarina, Rua Beloni Trombeta Zanini, 680E, 89815-630 Chapecó, SC, Brazil \\ ${ }^{3}$ Programa de Pós-Graduação em Ciência e Tecnologia de Alimentos, Centro de Ciências Rurais, \\ Universidade Federal de Santa Maria, Avenida Roraima, 1000, 97105-900 Santa Maria, RS, Brazil \\ ${ }^{4}$ Departamento de Microbiologia e Parasitologia, Universidade Federal de Santa \\ Maria, Avenida Roraima, 1000, 97105-900 Santa Maria, RS, Brazil \\ ${ }^{5}$ Departamento de Zootecnia, Universidade Tecnológica Federal do Paraná, Estrada p/ \\ Boa Esperança, s/n - Zona Rural, 85660-000 Dois Vizinhos, PR, Brazil \\ ${ }^{6}$ Instituto de Agronomia do Paraná, Rodovia BR-158, 5517 SR - Bom Retiro, 85501-970 Pato Branco, PR, Brazil
}

Manuscript received on June 19, 2017; accepted for publication on August 7, 2017

\begin{abstract}
The aim of this study was to modify the fatty acid profile of yogurt from sheep milk by the inclusion of different concentrations of palm oil into their diet. Thus, thirty-six sheep during lactation were separated in four groups with nine animals each, as described below: the group T0 $(0 \%)$; the group T2 (inclusion of $2 \%$ of palm oil); the group T4 (inclusion of $4 \%$ of palm oil) and the group T6 (inclusion of $6 \%$ of palm oil). After 60 days of the supplementation, milk samples were collected and yogurt was produced, which was evaluated regarding the concentration of saturated fatty acids (SFA), monounsaturated fatty acids (MFA), and polyunsaturated fatty acids (PFA). A significant reduction $(\mathrm{p}<0.05)$ in most SFA and a significant increase $(p<0.05)$ on MFA and PFA was observed in the yogurt of sheep supplemented with 4 and $6 \%$ of palm oil. Consequently, it is possible to conclude that palm oil supplementation exerts positive effects on yogurt, since it led to the reduction of undesirable fatty acids and increased fatty acids beneficial to human health.
\end{abstract}

Key words: fatty acids, palm oil, sheep, yogurt.

\section{INTRODUCTION}

Lately, there is a great interest to produce functional foods with physiological benefits to the health of consumers, such as those called nutraceutical

Correspondence to: Aleksandro Schafer da Silva

E-mail: aleksandro_ss@yahoo.com.br foods. These products are food or part of food able to prevent or reduce diseases (Pandey et al. 2010), and can be obtained by a nutritional modulation of food animals, being the sheep milk an example of food with nutritional properties. The sheep milk is recognized by its high content of protein, calcium, phosphorus and lipids, being considered 
an adequate food to produce fine cheeses and yogurt (Park et al. 2007, Stubbs et al. 2009). Yogurt is a product of the acidic fermentation of milk by bacterial cultures of Lactabacillus delbrueckii, and it has shown antimicrobial effect against several pathogenic bacteria, being considered a functional food that may mitigate coronary heart disease, osteoporosis and bowel disorders (Brandão 2002). Thus, the modulation of sheep milk content can make this food a functional food.

The fatty acid profile of sheep milk is composed mainly by short and medium-chain fatty acids, highlighting its beneficial characteristics for individuals with lipid malabsorption syndrome, i.e., people with difficulties to digest long chain triacylglycerol (Mora-Gutierrez et al. 2007). On the other hand, fatty acid composition of sheep milk is mainly based on saturated fatty acids (SFA), such as lauric acid (C12:0), myristic acid (C14:0), and palmitic acid (C16:0). These fatty acids have hypercholesterolemic characteristics which increases the risk of cardiac diseases, compromising the consumption of sheep milk derivatives (Zhang et al. 2006, Branciari et al. 2012).

Short and medium-chain fatty acids are not well accepted by consumers, since long-chain fatty acids are considered healthier. Among these polyunsaturated fatty acids (PFA), the alphalinolenic, conjugated linoleic (CLA) and omega 3 fatty acids (eicosapentaenoic acid - EPA and docosahexaenoic acid - DHA) are known as the best for human health with protective action on the cardiovascular system, as well as antitumoral and immune-stimulant effects (Parodi 2004). Considering these problems and the need for foods with additional benefits to human health, dietary supplementation with natural products can be considered an important alternative to reduce SFA and to increase PFA in sheep milk (Gómez-Cortés et al. 2009). In this sense, the use of fatty products in the diet is considered an important approach to alter the milk lipid profile, since lipids are better source of energy compared to carbohydrates, enabling the reduction of concentrate to feed dairy animals (Stoffel et al. 2015).

Oil supplementation of dairy sheep has been considered an important approach to alter milk lipid profile (Zhang et al. 2006, Luna et al. 2008, Branciari et al. 2012), and the response regarding this addition has led to an increase on long-chain fatty acids, mainly CLA and $\alpha$-linolenic fatty acids, as well as the reduction on short and medium-chain fatty acids, such as lauric, myristic, and palmitic fatty acids (Bhat and Bhat 2011). Changes on milk lipid profile depend on the type of oil, quantity, the profile of fatty acids on milk, as well as the composition of diet (forage ratio, concentrate and fiber digestibility) and lactation stage (Sampelayo et al. 2007, Shingfield et al. 2008). The use of vegetable oils provided in the natural form can exert negative effects to animals, such as the reduction on fiber digestibility. Thus, the use of protected fat can be considered an important alternative, since it does not suffer alterations on ruminal environment (Smith 1990).

Several oils can be used as a good source of fatty acids in the form of protected fat to feed ruminants, such as the palm oil (Bianchi et al. 2014). This oil is rich in carotenoids, vitamin $\mathrm{E}$ and antioxidants (Cesco et al. 2013), and presents $50 \%$ of SFA on its composition, being $44 \%$ of palmitic fatty acid and $5 \%$ of stearic fatty acid (C18:0). The UFA corresponds approximately to $40 \%$ of oleic acid (C18:1) and 10\% of polyunsaturated linoleic acid (C18:2) and linolenic acid (C18:3) (Cottrell 1991, Sambanthamurthi et al. 2000). Due to these characteristics, the aim of this study was to evaluate the fatty acid profile of yogurt after palm oil supplementation in the form of protected fat at different concentrations to dairy sheep.

\section{MATERIALS AND METHODS}

\section{ANIMALS AND EXPERIMENTAL DESIGN}

The current study used 36 lactating Lacaune ewes, two to four years of age, on their second or third 
lactation, with one or two offspring as previously described (Bianchi et al. 2014). Animals were separated into four treatments based on their body weight, age, parity order, number of lambs, and milk production. The treatments consisted of diet with $0 \%$ (T0), $2 \%$ (T2), 4\% (T4) and 6\% (T6) of protected fat from palm oil. The feed composition was corn silage, corn ground, soybean meal, wheat bran and calcium soap (palm oil), as previously described (Bianchi et al. 2014). This protocol was approved by the Animal Ethics Committee of the Universidade Tecnológica Federal do Paraná.

\section{MILK SAMPLING}

Sheep milk was automatically collected after 60 days after the beginning of the experiment every day at 05:00 PM. Immediately after sampling, milk of each group was homogenate in plastic buckets ( 2 ${ }^{\circ} \mathrm{C}$ ) to prepare yogurt. The centesimal composition of milk was previously published by Bianchi et al. (2014) and the levels of fat did not differ between treatments as follows: $\mathrm{T} 0-6.32 \pm 0.76, \mathrm{~T} 2-6.35 \pm$ $0.65, \mathrm{~T} 4-6.44 \pm 0.63$ and $\mathrm{T} 6-6.25 \pm 1.29$.

\section{YOGURT PRODUCTION}

The milk was heated at $90{ }^{\circ} \mathrm{C}$ during $5 \mathrm{~min}$ and chilled to $42^{\circ} \mathrm{C}$ before the addition of starter culture (50 U/250L of milk) responsible for the acidic fermentation and yogurt production, followed by homogenation for $5 \mathrm{~min}$ and incubation at $42{ }^{\circ} \mathrm{C}$ for $5 \mathrm{~h}$ up to $\mathrm{pH} 4.4$ to 4.6 . Later, the yogurt was rapidly cooled $\left(2{ }^{\circ} \mathrm{C}\right)$ in a cold chamber during $5 \mathrm{~h}$. After this time, three samples per treatment were frozen $\left(-20^{\circ} \mathrm{C}\right)$ and sent to the laboratory in order to evaluate the fatty acid profile.

\section{DETERMINATION OF YOGURT FATTY ACID PROFILE}

The yogurt samples were thawed under refrigeration $\left(7 \pm 1^{\circ} \mathrm{C}\right)$, homogenized and processed to extract lipids, according to the methodology described by
Bligh and Dyer (1959). Four grams of sample were weighted directly in Falcon tubes $(50 \mathrm{~mL})$ with 8 $\mathrm{mL}$ of chloroform, $16 \mathrm{~mL}$ of ethanol and $3 \mathrm{~mL}$ of distilled water, followed by homogenization with a Homogenizer type Turrax. After, the tubes were mixed during $30 \mathrm{~min}$ with the addition of $8 \mathrm{~mL}$ of chloroform and $8 \mathrm{~mL}$ of anhydrous sodium sulfate $(1.5 \%)$. Afterwards, the tubes were centrifuged for $5 \mathrm{~min}$, and the lower phase was conditioned in a new Falcon tube $(20 \mathrm{~mL})$ containing $1 \mathrm{~g}$ of anhydrous sodium sulfate, in order to remove the excess of water. After filtering with filter paper, $1.5 \mathrm{~mL}$ of the filtered was stored in assay tubes for subsequent drying in a vacuum evaporator.

The extracted fat was esterified according to a specific methodology described by Hartman and Lago (1973). Briefly, fat was mixed with $0.5 \mathrm{~mL}$ of potassium hydroxide ( $\mathrm{KOH} 0.4 \mathrm{M})$ in methanol and mixed until total homogenization. After, the samples were heated at $100{ }^{\circ} \mathrm{C}$ during $10 \mathrm{~min}$, and cooled at room temperature. It was added $1.5 \mathrm{~mL}$ of sulfuric acid $\left(\mathrm{H}_{2} \mathrm{SO}_{4} 1 \mathrm{M}\right)$ dissolved in methanol, and the samples returned to heating at $100{ }^{\circ} \mathrm{C}$ for $10 \mathrm{~min}$. The samples were cooled at room temperature, and $2 \mathrm{~mL}$ of $\mathrm{n}$-hexane was added in order to separate the phases. After separation, the supernatant was stored in micro tubes at $20^{\circ} \mathrm{C}$.

Theesterswereanalyzedbygaschromatography (Agilent Technologies, series 6890N), equipped with a fused silica capillary column $(100 \mathrm{~m}$ long $\mathrm{x}$ $0.25 \mathrm{~mm}$ internal diameter $\mathrm{x} 0.2 \mu \mathrm{m}$ film thickness) and flame ionization detector (FID). The column was heated at $35^{\circ} \mathrm{C}$ during $2 \mathrm{~min}$, increasing $10^{\circ} \mathrm{C}$ per minute up to $150{ }^{\circ} \mathrm{C}$ during $2 \mathrm{~min}$. After, the temperature was increased $2{ }^{\circ} \mathrm{C}$ per minute up to $200^{\circ} \mathrm{C}$, remaining for 2 minutes at this temperature. Again, the temperature was increased $2{ }^{\circ} \mathrm{C}$ per minute until $220^{\circ} \mathrm{C}$, remaining in this temperature for $21 \mathrm{~min}$, totalizing 73.5 minutes. Nitrogen was used as drag gas $\left(0.9 \mathrm{~mL} \mathrm{~min}^{-1}\right)$. The volume of the sample injected (split mode) was $1 \mu \mathrm{L}$. The temperature used in the FID was $280{ }^{\circ} \mathrm{C}$. The fatty 
acids were identified by comparison with retention times of reference standards (Supelco 37 FAME Mix, Bellefonte, EUA).

\section{STATISTICAL ANALYSES}

Normality test showed that the results were normal. Therefore, the fatty acids profile in yogurt was submitted to variance analysis (ANOVA), followed by Tukey test by comparing means and precision $(p<0.05)$. The results were shown as mean and standard deviation.

\section{RESULTS}

The addition of palm oil in the diet of Lacaune sheep altered the yogurt fatty acid profile. SFA levels (Table I) were lower $(\mathrm{p}<0.05)$ in animals supplemented with 4 or $6 \%$ of palm oil compared to those of groups T0 (0\%) and T2 (2\%). This alteration was mainly regarding butyric $(\mathrm{C} 4: 0)$, undecanoic (C11:0), pentadecanoic (C15:0), stearic (C18:0) and arachidic (C20:0) contents. Lower levels of hexanoic (C6:0) and palmitic (C16:0) fatty acids was observed on all concentrations of tested palm oil compared to the control group. On the other hand, the levels of capric acid (C10:0), lauric (C12:0) and behenic (C22:0) were higher $(p<0.05)$ in the groups T4 and T6 compared to the control group. No difference was observed between groups regarding the myristic fatty acid (C14:0).

Yogurt MFA content for all supplemented groups was also reduced $(\mathrm{p}<0.05)$ compared to the control group (Table II). Regarding this alteration, a reduction $(p<0.05)$ for the concentration of myristoleic (C14:1), transvacenic (C18: 1t11) and heptadecanoic (C17:11) fatty acids was observed in the groups T4 and T6 compared to T0, while the levels of palmitoleic fatty acid (C16:1) were reduced in the group T2 compared to T0. However, a significant increase $(p<0.05)$ of elaidic fatty acid (C18:1n9t) was observed in the yogurt from the group T2 compared to all treatments. Moreover, a significant increase $(p<0.05)$ of oleic acid was observed in the groups supplemented with 4 and $6 \%$ of palm oil compared to the control group.

\section{TABLE I}

Mean and standard deviation of saturated fatty acids (SFA) in yogurt of sheep supplemented with palm oil (0, 2, 4 and $6 \%)$ during 60 days.

\begin{tabular}{|c|c|c|c|c|c|}
\hline \multirow{2}{*}{ Variables } & \multicolumn{5}{|c|}{ Mean \pm standard deviation } \\
\hline & Palm oil $(0 \%)$ & Palm oil (2\%) & Palm oil (4\%) & Palm oil (6\%) & $\mathrm{p}$ \\
\hline $\mathrm{C} 4: 0$ & $0.97 \pm 0.05^{\mathrm{a}}$ & $0.95 \pm 0.03^{\mathrm{a}}$ & $0.64 \pm 0.021^{\mathrm{b}}$ & $0.66 \pm 0.018^{\mathrm{b}}$ & $<0.05$ \\
\hline $\mathrm{C} 6: 0$ & $0.85 \pm 0.02^{\mathrm{a}}$ & $0.77 \pm 0.045^{\mathrm{b}}$ & $0.77 \pm 0.032^{\mathrm{b}}$ & $0.75 \pm 0.024^{\mathrm{b}}$ & $<0.05$ \\
\hline $\mathrm{C} 8: 0$ & $0.63 \pm 0.008^{\mathrm{b}}$ & $0.54 \pm 0.004^{\mathrm{c}}$ & $0.95 \pm 0.021^{\mathrm{a}}$ & $0.96 \pm 0.036^{\mathrm{a}}$ & $<0.05$ \\
\hline $\mathrm{C} 10: 0$ & $1.72 \pm 0.21^{\mathrm{b}}$ & $1.38 \pm 0.17^{\mathrm{c}}$ & $3.87 \pm 0.45^{\mathrm{a}}$ & $3.83 \pm 0.18^{\mathrm{a}}$ & $<0.05$ \\
\hline $\mathrm{C} 11: 0$ & $0.20 \pm 0.07^{\mathrm{a}}$ & $0.21 \pm 0.03^{\mathrm{a}}$ & $0 \pm 0^{\mathrm{b}}$ & $0 \pm 0^{\mathrm{b}}$ & $<0.05$ \\
\hline $\mathrm{C} 12: 0$ & $2.32 \pm 0.32^{\mathrm{b}}$ & $1.91 \pm 0.41^{\mathrm{b}}$ & $3.0 \pm 0.24^{\mathrm{a}}$ & $2.97 \pm 0.14^{\mathrm{a}}$ & $<0.05$ \\
\hline $\mathrm{C} 14: 0$ & $10.4 \pm 1.2^{\mathrm{a}}$ & $9.22 \pm 1.35^{\mathrm{a}}$ & $10.56 \pm 2.0^{\mathrm{a}}$ & $10.41 \pm 1.5^{\mathrm{a}}$ & $>0.05$ \\
\hline C15:0 & $1.22 \pm 0.2^{\mathrm{a}}$ & $1.21 \pm 0.4^{\mathrm{a}}$ & $0 \pm 0^{\mathrm{b}}$ & $0 \pm 0^{\mathrm{b}}$ & $<0.05$ \\
\hline $\mathrm{C} 16: 0$ & $32.7 \pm 0.41^{\mathrm{a}}$ & $30.1 \pm 0.5^{\mathrm{b}}$ & $28.7 \pm 0.4^{c}$ & $28.8 \pm 0.6^{\mathrm{c}}$ & $<0.05$ \\
\hline C18:0 & $17.5 \pm 1.2^{\mathrm{a}}$ & $18.9 \pm 0.9^{\mathrm{a}}$ & $13.4 \pm 0.5^{b}$ & $13.6 \pm 0.9^{b}$ & $<0.05$ \\
\hline $\mathrm{C} 20: 0$ & $0.28 \pm 0.04^{\mathrm{a}}$ & $0.31 \pm 0.01^{\mathrm{a}}$ & $0 \pm 0^{\mathrm{b}}$ & $0 \pm 0^{\mathrm{b}}$ & $<0.05$ \\
\hline $\mathrm{C} 22: 0$ & $0 \pm 0^{\mathrm{b}}$ & $0 \pm 0^{\mathrm{b}}$ & $0.12 \pm 0.02^{\mathrm{a}}$ & $0.12 \pm 0.02^{\mathrm{a}}$ & $<0.05$ \\
\hline
\end{tabular}

Note: $\mathrm{p}<0.05$ indicate difference between groups. Different letters in the same line show differences between groups. Butyric acid (C4:0), hexanoic acid (C6:0), caprylic acid (C8:0), capric acid (C10:0), undecanoic acid (C11:0), lauric acid (C12:0), myristic acid (C14:0), pentadecanoic acid (C15:0), palmitic acid (C16:0), stearic acid (C18:0), arachidic acid (C20:0) and behenic acid (C22:0). 
TABLE II

Mean and standard deviation of monounsaturated fatty acids (MFA) in yogurt of sheep supplemented with palm oil (0, 2 , 4 and $6 \%$ ) during 60 days.

\begin{tabular}{cccccc}
\hline \multirow{2}{*}{ Variables } & \multicolumn{3}{c}{ Mean \pm standard deviation } \\
\cline { 2 - 5 } & Palm oil $(0 \%)$ & Palm oil $(2 \%)$ & Palm oil (4\%) & Palm oil (6\%) & $\mathrm{p}$ \\
\hline C14:1 & $0.86 \pm 0.04^{\mathrm{a}}$ & $0.72 \pm 0.06^{\mathrm{a}}$ & $0 \pm 0^{\mathrm{b}}$ & $0 \pm 0^{\mathrm{b}}$ & $<0.05$ \\
C16:1 & $1.5 \pm 0.24^{\mathrm{a}}$ & $1.26 \pm 0.09^{\mathrm{b}}$ & $1.47 \pm 0.14^{\mathrm{a}}$ & $1.37 \pm 0.17^{\mathrm{ab}}$ & $<0.05$ \\
C17:1 & $0.27 \pm 0.05^{\mathrm{a}}$ & $0.29 \pm 0.02^{\mathrm{a}}$ & $0 \pm 0^{\mathrm{b}}$ & $0 \pm 0^{\mathrm{b}}$ & $<0.05$ \\
C18:1t11 & $3.40 \pm 0.6^{\mathrm{a}}$ & $3.71 \pm 0.9^{\mathrm{a}}$ & $2.28 \pm 0.24^{\mathrm{b}}$ & $2.22 \pm 0.18^{\mathrm{b}}$ & $<0.05$ \\
C18:1 n9t & $0.43 \pm 0.04^{\mathrm{b}}$ & $0.64 \pm 0.08^{\mathrm{a}}$ & $0.48 \pm 0.056^{\mathrm{b}}$ & $0.51 \pm 0.03^{\mathrm{b}}$ & $<0.05$ \\
C18:1n9C & $23.48 \pm 0.5^{\mathrm{b}}$ & $25.29 \pm 0.2^{\mathrm{b}}$ & $27.91 \pm 0.7^{\mathrm{a}}$ & $28.27 \pm 0.9^{\mathrm{a}}$ & $<0.05$ \\
\hline
\end{tabular}

Note: $\mathrm{p}<0.05$ indicate difference between groups. Different letters in the same line show differences between groups. Myristoleic acid (C14:1), palmitoleic acid (C16:1), heptadecanoic acid (C17:1), transvacenic acid (C18:1t11), elaidic acid (C18:1n9t) and oleic acid (C18: $\ln 9 \mathrm{C})$.

TABLE III

Mean and standard deviation of polyunsaturated fatty acids (PFA) in yogurt of sheep supplemented with palm oil (0, 2, 4 and $6 \%$ ) during 60 days.

\begin{tabular}{cccccc}
\hline \multirow{2}{*}{ Variables } & \multicolumn{3}{c}{ Mean \pm standard deviation } \\
\cline { 2 - 6 } & Palm oil $(0 \%)$ & Palm oil $(2 \%)$ & Palm oil $(4 \%)$ & Palm oil $(6 \%)$ & $\mathrm{p}$ \\
\hline C18:2n6T & $0 \pm 0^{\mathrm{b}}$ & $0 \pm 0^{\mathrm{b}}$ & $0.28 \pm 0.02^{\mathrm{a}}$ & $0.31 \pm 0.05^{\mathrm{a}}$ & $<0.05$ \\
C18:2n6C & $0 \pm 0^{\mathrm{c}}$ & $1.21 \pm 0.05^{\mathrm{b}}$ & $3.63 \pm 0.06^{\mathrm{a}}$ & $3.33 \pm 0.07^{\mathrm{a}}$ & $<0.05$ \\
C18:3n3 & $0 \pm 0^{\mathrm{c}}$ & $0.30 \pm 0.03^{\mathrm{b}}$ & $0.58 \pm 0.021^{\mathrm{a}}$ & $0.55 \pm 0.03^{\mathrm{a}}$ & $<0.05$ \\
CLA & $0.95 \pm 0.04^{\mathrm{ab}}$ & $1.0 \pm 0.024^{\mathrm{a}}$ & $0.91 \pm 0.03^{\mathrm{b}}$ & $0.92 \pm 0.044^{\mathrm{b}}$ & $<0.05$ \\
C20:4n6 & $0 \pm 0^{\mathrm{b}}$ & $0 \pm 0^{\mathrm{b}}$ & $0.28 \pm 0.036^{\mathrm{a}}$ & $0.26 \pm 0.047^{\mathrm{a}}$ & $<0.05$ \\
\hline
\end{tabular}

Note: $\mathrm{p}<0.05$ indicate difference between groups. Different letters in the same line show differences between groups. Linolelaidic acid (C18: 2n6T), linoleic acid (C18:2n6C), alpha-linolenic acid (C18:3n3), conjugated linolenic acid (CLA) and arachidonic acid (C20:4n6).

The content of PFA in yogurt is shown in Table III. A significant increase of linolelaidic, linolenic, conjugated linolenic (CLA) and arachidonic (C20:4n6) fatty acids was observed in groups supplemented with 4 and $6 \%$ of oil compared to the control group. In addition, a significant increase $(p<0.05)$ of alpha-linoleic fatty acid $(\mathrm{C} 18: 2 \mathrm{n} 6 \mathrm{C})$ was observed in groups T2, T4 and T6 compared to the control group.

A significant reduction $(\mathrm{p}<0.05)$ on SFA content in yogurt was observed in groups treated with 4 and $6 \%$ of palm oil compared to the control group (Table IV). Yogurt MFA and PFA values, in general, increased $(p<0.05)$ in animals supplemented with palm oil compared to the control group. Moreover, the relation PFA/SFA increased $(p<0.05)$ in yogurt from palm oil supplemented sheep compared to the control group (Table IV).

\section{DISCUSSION}

Lipidic supplementation, mainly by those rich in PFA is efficient to reduce short and medium-chain fatty acids of milk Baumann et al. (2016), which is desirable since these fatty acids are frequently linked to human coronary diseases (Ebbesson et al. 2015). In this study, we observed a reduction on SFA content, as well as an increase on MFA and PFA contents, demonstrating that palm oil supplementation exerts positive effects on sheep milk.

In addition to the fatty acid profile of the oil to be used, it is necessary attention to the concentration 
TABLE IV

Mean and standard deviation of the sum of saturated fatty acids ( $\sum$ SFA), monounsaturated fatty acids $\left(\sum\right.$ MFA) and polyunsaturated fatty acids ( $\sum$ PFA) in milk of sheep supplemented with palm oil $(0,2,4$ and $6 \%)$ during 60 days.

\begin{tabular}{cccccc}
\hline \multirow{2}{*}{ Variables } & \multicolumn{5}{c}{ Mean \pm standard deviation } \\
\cline { 2 - 6 } & Palm oil (0\%) & Palm oil (2\%) & Palm oil (4\%) & Palm oil (6\%) & $\mathrm{p}$ \\
\hline$\sum$ SFA & $69.1 \pm 0.3$ & $66.1 \pm 0.09$ & $62.1 \pm 0.51$ & $62.2 \pm 0.08$ & $<0.05$ \\
$\sum$ MFA & $29.9 \pm 0.05$ & $31.9 \pm 0.6$ & $32.1 \pm 0.45$ & $32.3 \pm 0.21$ & $<0.05$ \\
$\sum$ PFA & $0.95 \pm 0.04$ & $1.93 \pm 0.06$ & $5.74 \pm 0.3$ & $5.37 \pm 0.15$ & $<0.05$ \\
$\sum$ PFA $/ \sum$ SFA & $0.44 \pm 0.05$ & $0.51 \pm 0.038$ & $0.60 \pm 0.02$ & $0.60 \pm 0.026$ & $<0.05$ \\
\hline
\end{tabular}

Note: $\mathrm{p}<0.05$ indicate difference between groups. Different letters in the same line show differences between groups.

of the oil in the diet, since fat supplementation must vary between $4-5 \%$ of dry matter, an efficient amount still able to increase solids in the milk (Nudda et al. 2004). However, when fat supply exceeds these values, milk fat depression may occur due to the adhesion of ruminal microorganisms to the food, compromising the antimicrobial activity and, consequently, a reduction on short-chain fatty acid synthesis. Besides, it may occur the reduction of blood metabolites absorption from the mammary gland (Nudda et al. 2004), leading variable yogurt SFA content. The reduction of SFA of milk can occur since these fatty acids are originated from microbial lipids synthetized from propionate and valerate present in the rumen (Vlaeminck et al. 2006), and their presence in the milk might be linked to the synthesis of microbial fatty acids by microbial cells. In summary, these effects can be linked with the toxicity of unsaturated fatty acids (UFA) on ruminal microorganisms. Moreover, the increase on UFA and PFA content may be attributed to a significant increase of linoleic acid in the experimental groups, similarly to what was observed by Vizzarri et al. (2017) in meat of rabbits supplemented with three different natural products, such as the extracts of Lippia citriodora, Raphanus sativus and Solanum lycopersicum. The action mechanism might be linked with the presence of linoleic acid, since it is a precursor of $n 3$ and $n 6$ UFA family, and the reactions of elongation and desnaturation are mediated by the enzymes fatty
acil-CoA synthetases 6- and 5- desaturases, as well as by elongases (El-Shemy 2011).

Other explanation for the reduction on short and medium-chain fatty acids seen after the supplementation of palm oil is the extenuation of long-chain fatty acid from ruminal biohydrogenation, and consequently, inhibition on acetyl CoA carboxylase, which is the enzyme responsible for fatty acids synthesis in the mammary gland (Palmquist and Jenkins 1980). Due to a large quantity of long-chain fatty acid provided in the diet, the rescue of fatty acids from the mammary gland is stimulated, occurring an incomplete biohydrogenation and, consequently, the production of acids capable to inhibit the mammary gland lipogenesis (Bauman and Griinari 2001).

The oil seeds possess approximately $18-40 \%$ of fatty acids, mainly UFA. The palmitic, oleic and linoleic acids are the major compounds present in the palm oil (Palmquist and Mattos 2006) which explains the increase of these acids in the yogurt. The PFA are not synthetized by ruminant tissues, and its content depends on the quantity provided in the diet (not suffer biohydrogenation) and the amount absorbed by animals and incorporated into the milk fat (Luna et al. 2008).

In this study, the higher CLA content in the yogurt of the group treated with $6 \%$ of palm oil may be associated with the enzyme delta-9desaturase, responsible to convert the vaccenic acid 
(intermediate fatty acid in the biohydrogenation of linolenic acid) to rumenic acid, which is the predominant isomer of CLA in the mammary gland. It is reported that the use of palm oil as a source of lipid is able to increase CLA content, since it induces the attack of microorganisms to the source of energy, favoring the biohydrogenation process (Maia et al. 2006).

A significant increase on alpha-linolenic acid, a fatty acid belonging to omega 3 family and the main precursor of eicosapentaenoic acid (EPA) and docosahexaenoic acid (DHA), was observed in groups treated with palm oil (Perini et al. 2010). These fatty acids possess a fundamental importance to human health; these compounds are essential and directly associated to a reduction on cardiovascular diseases and hypertension.

Based on these evidences, the inclusion of palm oil in the diet of dairy sheep modulates the fatty acid content in yogurt, reducing the SFA levels and increasing the MFA and PFA. These results are promising, and indicate that palm oil can be considered an important energetic source to ruminal feeding, inhibiting the production of short and medium-chain fatty acids, as well as increasing the production of long-chain fatty acids that may exert beneficial effects to human health.

\section{REFERENCES}

BAUMAN DE AND GRIINARI JM. 2001. Regulation and nutritional manipulation of milk fat: low-fat milk syndrome. Livest Prod Sci 70: 15-29.

BAUMANN E, CHOUINARD PY, LEBEUF Y, RICO DE AND GERVAIS R. 2016. Effect of lipid supplementation on milk odd-and branched-chain fatty acids in dairy cows. J Dairy Sci 99: 6311-6323.

BHAT ZF AND BHAT H. 2011. Milk and dairy products as functional foods: a review. Int J Dairy Sci 6: 1-12.

BIANCHI AE ET AL. 2014. Effect of adding palm oil to the diet of dairy sheep on milk production and composition, function of liver and kidney, and the concentration of cholesterol, triglycerides and progesterone in blood serum. Small Rum Res 117: 78-83.
BLIGH EG AND DYER WJ. 1959. A rapid method of total lipid extraction and purification. Can J Bioch Physiol 37: 911-917.

BRANCIARI R, VALIANI A, TRABALZA-MARINUCCI M, MIRAGLIA D, RANUCCI D, ACUTI G, ESPOSTO S AND MUGHETTI L. 2012. Consumer acceptability of ovine cheese from ewes fed extruded linseed-enriched diets. Small Rum Res 106: 43-48.

BRANDÃO SCC. 2002. Novas gerações de produtos lácteos funcionais. Revista Indústria de Laticínios, São Paulo 6(37): 64-66.

CESCO G, BIANCHI AE AND MACED VP. 2013. Produção e composição química do leite de ovelhas Lacaune alimentadas com gordura protegida. Synerg Scy UTFPR 8: $1-3$.

COTTRELL RC. 1991. Introduction: nutritional aspects of palm oil. Amer J Clin Nut 53: 989S-1009S.

EBBESSON SOE ET AL. 2015. Fatty acids linked to cardiovascular mortality are associated with risk factors. Int J Circumpolar Health 74: 28055.

EL-SHEMY H. 2011. Metabolism of $\alpha$-linolenic acid (ALA) in meat animals. Soybean and Nutrition, InTech Rijeka, Croatia.

GÓMEZ-CORTÉS P, BACH A, LUNA P, JUÁREZ M AND DE LA FUENTE MA. 2009. Effects of extruded linseed supplementation on n-3 fatty acids and conjugated linoleic acid in milk and cheese from ewes. J Dairy Sci 92: 41224134.

HARTMAN L AND LAGO RC. 1973. A Rapid preparation of fatty acid methyl esters from lipids. Lab Pract 22: 475-477.

LUNA P, BACH A, JUÁREZ M AND DE LA FUENTRE MA. 2008. Influence of diets rich in flax seed and sunflower oil on the fatty acid composition of ewes' milk fat especially on the level of conjugated linoleic acid, n-3 and n-6 fatty acids. Int Dairy J 18: 99-107.

MAIA FJ, BRANCO AF, MOURO GF, CONEGLIAN SM, DOS SANTOS GT, MINELLA TF AND GUIMARÃES KC. 2006. Inclusão de fontes de óleo na dieta de cabras em lactação: produção, composição e perfil dos ácidos graxos do leite. Rev Bras Zootec 35: 1504-1513.

MORA-GUTIERREZ A, FARRELL HM, ATTAIE R, MCWHINNEY VJ AND WANG C. 2007. Effects of bovine and caprine Monterey Jack cheeses fortified with milk calcium on bone mineralization in rats. Int Dairy J 17: 255-267.

NUDDA A, BATTACONE G, BENCIN R AND PULINA G. 2004. Nutritional and milk quality. Dairy Sheep Nutrition, Oxsfordshire, p. 129-150.

PALMQUIST DL AND JENKINS TC. 1980. Fat in Lactation Rations 1, 2: Review. J Dairy Sci 63:1-14.

PALMQUIST DL AND MATTOS W. 2006. Metabolismo de lipídeos. Nutrição de Ruminantes, Jaboticabal, p. 151-182. 
PANDEY M, VERMA RK AND SARAF SA. 2010. Nutraceuticals: new era of medicine and health. Asian J Pharm Clin Res 3: 11-15.

PARK YW, JUÁREZ M, RAMOS M AND HAENLEIN GFW. 2007. Physico-chemical characteristics of goat and sheep milk. Small Rum Res 68: 88-113.

PARODI PW. 2004. Milk fat in human nutrition. Aust J Dairy Techn 59: 3-59.

PERINI JADL, STEVANATO FB, SARGI SC, VISENTAINER JEL, DALALIO MMDO, MATSHUSHITA M AND VISENTAINER JV. 2010. Omega-3 and omega-6 polyunsaturated fatty acids: metabolism in mammals and immune response. Rev Nutr 23: 1075-1086.

SAMBANTHAMURTHI R, SUNDRAM K AND TAN Y. 2000. Chemistry and biochemistry of palm oil. Prog Lipid Res 39: 507-558.

SAMPELAYO MS, CHILLIARD Y, SCHMIDELY P AND BOZA J. 2007. Influence of type of diet on the fat constituents of goat and sheep milk. Small Rum Res 68: 42-63.

SHINGFIELD KJ, CHILLIARD Y, TOIVONEN V, KAIRENIUS P AND GIVENS DI. 2008. Trans fatty acids and bioactive lipids in ruminant milk. Adv Exp Med Biol 606: 3-65.
SMITH W. 1990. Fats for lactations dairy cows. Congress of the South Africa Socity and Animal Production, Stellenbosch, p. 1-10.

STOFFEL CMP, CRUMP M AND ARMENTANO LE. 2015. Effect of dietary fatty acid supplements, varying in fatty acid composition, on milk fat secretion in dairy cattle fed diets supplemented to less than $3 \%$ total fatty acids. J Dairy Sci 98: 431-442.

STUBBS A, ABUD G AND BENCINI R. 2009. Dairy sheep manual: farm management guidelines. Rural Res Dev Corp, p. 69.

VIZZARRI F, PALAZZO M, D’ALESSANDRO AG AND CASAMASSIMA A. 2017. Productive performance and meat quality traits in growing rabbit following the dietary supplementation of Lippia citriodora, Raphanus sativus and Solanum lycopersicum extracts. Livest Sci 200: 53-59.

VLAEMINCK B, FIEVEZ V, DEMEYER D AND DEWHURST RJ. 2006. Effect of forage: concentrate ratio on fatty acid composition of rumen bacteria isolated from ruminal and duodenal digesta. J Dairy Sci 89: 2668-2678.

ZHANG RH, MUSTAFA AF AND ZHAO X. 2006. Effects of feeding oilseeds rich in linoleic and linolenic fatty acids to lactating ewes on cheese yield and on fatty acid composition of milk and cheese. Anim Feed Sci Techn 127: $220-233$. 